\title{
A Comprehensive Review of Backfill Materials and Their Effects on Ground Heat Exchanger Performance
}

\author{
Hossein Javadi $^{1}$, Seyed Soheil Mousavi Ajarostaghi ${ }^{2, *}$, , Marc A. Rosen ${ }^{3}$ (i) \\ and Mohsen Pourfallah ${ }^{1}$ (D) \\ 1 Department of Mechanical Engineering, Mazandaran University of Science and Technology, \\ Babol 47166-85635, Iran; h.javadi994@ustmb.ac.ir (H.J.); m.pourfallah@ustmb.ac.ir (M.P.) \\ 2 Department of Mechanical Engineering, Babol Noshirvani University of Technology, Babol 47148-71167, Iran \\ 3 Faculty of Engineering and Applied Science, University of Ontario Institute of Technology, \\ 2000 Simcoe Street North, Oshawa, ON L1G 0C5, Canada; Marc.Rosen@uoit.ca \\ * Correspondence: s.s.mousavi@stu.nit.ac.ir
}

Received: 6 November 2018; Accepted: 24 November 2018; Published: 28 November 2018

\begin{abstract}
Geothermal energy systems can help in achieving an environmentally friendly and more efficient energy utilization, as well as enhanced power generation and building heating/cooling, thereby making energy systems more sustainable. The role of the backfill material, which fills the space between a pipe and the surrounding soil, is important in the operation of ground heat exchangers. Among the review articles on parameters affecting ground heat exchanger performance published over the past eight years, only two discuss types of backfill materials, even though the importance of these materials is significant. However, no review has yet been published exclusively on the kinds of backfill materials used in ground heat exchangers. This article addresses this need by providing a comprehensive review of a variety of types of backfill materials and their effects on ground heat exchanger performance. For organizational purposes, the backfill materials are divided into two categories: conventional backfill materials (pure and mixed materials) and modern backfill materials (improved phase change materials). Both categories are described in detail. It is shown that bentonite has been used considerably as a conventional backfill material in ground heat exchangers, followed by silica sand and coarse/fine sand. Moreover, acid and shape-stabilized phase change materials have been applied mostly as modern backfill materials in ground heat exchangers. It is observed, generally, that conventional backfill materials are used more than modern backfill materials in ground heat exchangers. It should be noted that the data covered in this study are not from all the articles published in the last eight years, but rather from a subset based on specific criteria (i.e., English-language papers published in reputable journals). These articles were published by authors from numerous countries. The results may, as a consequence, have some corresponding limitations, but these are likely to be minor.
\end{abstract}

Keywords: ground-source heat pump; ground heat exchanger; backfill material; phase change material

\section{Introduction}

A sustainable supply of energy resources is needed to move towards and ultimately achieve sustainable development. Such a supply would be sustainably available for all areas at a reasonable cost and without any negative effects on the environment. In order to achieve environmentally friendly and more efficient energy utilization, as well as an improved power generation and building heating/cooling, geothermal energy systems can play a significant role. However, their performance 
depends on various parameters, including monitoring and evaluation tools, financial mechanisms, sustainable energy programs, innovative energy and exergy strategies, environmental education and training, information, and public awareness [1-7]. Geothermal energy resources vary in depth from deep (several kilometers) to relatively shallow (tens to several hundreds of meters). Environmental impacts in terms of greenhouse gas emissions from this type of energy are typically relatively minor [6]. A wide range of applications, such as industrial processes, power generation, and building heating/cooling, exist for geothermal energy, leading to an increase in its utilization in recent years. Geothermal energy can be used for heating in cold seasons and cooling in warm seasons, and can be installed almost anywhere. The exploitation of geothermal energy in a closed loop geothermal system is performed using a ground-source heat pump (GSHP) unit, in which a ground heat exchanger (GHE) plays an important role. Depending on the available space and geographic conditions of an area, vertical or horizontal GHEs can be used [7].

The thermal resistance of the borehole in a closed loop vertical GHE greatly affects the system efficiency, and depends on the thermal properties of the backfill material utilized between the soil and the GHE pipe. The choice of the backfill material in a GHE is important since the main influential parameters on GHE performance are the thermo-physical and hydro-geological conditions of the ground and the thermal conductivity of the backfill material. Increasing the thermal conductivity of the backfill material normally improves the efficiency of GHEs [8,9]. In addition to the influence of this material on internal borehole heat transfer, it also affects the size of the GHEs [10-17]. When these backfill materials have a high thermal conductivity, heat exchange between the borehole wall and pipes can be increased $[18,19]$. The influence of the backfill thermal conductivity on effectiveness, in terms of the heat transfer efficiency of the ground heat exchanger, varies with operation time. Although the heat transfer capacity of a GHE increases with thermal conductivity, it also increases thermal shorting-circuiting, which is a factor in the rapid reduction of the effectiveness coefficient. There are many criteria for the selection of suitable backfill material. These depend on the operation conditions of the GHE, heat transfer capacity, geological features, and economic conditions.

Many studies have been performed on backfill materials. The effect of backfill material on the temperature distribution of vertical GHEs was investigated by Philippacopoulos and Allan [20,21]. Their results showed that connection quality between backfill material and pipes is important, and that the space between the pipe and the borehole wall should not be filled with a high shrinkage backfill material, because it can reduce the heat flux in the area around the pipe. Smith and Perry [22] examined the effect of backfill material on the heat transfer rate. They concluded that in order to avoid a reduction of system efficiency, the thermal conductivity of the backfill material should be as high as possible. A thermal conductivity range of 1.7-2.5 W/m.K for backfill materials was reported by Chulho Lee et al. [9]. It should be noted that guidelines for optimum design and installation methods of GHEs and rheological properties of sealing material are provided by the American Society of Heating, Refrigerating and Air-Conditioning Engineers (ASHRAE) from the United States, the Association of German Engineers (VDI) from Germany, and the British Standards (BS) from the UK. Being a waterproof, long-lasting, and frost-proof material, as well as creating good thermal conductivity between the pipes and surrounding soil, are the main features of the backfill material $[23,24]$. In order to ensure that the insulation of a borehole is in good condition, the backfill material must have specific mechanical and hydraulic properties. It should be noted that the instructions given in the guidelines noted above are based only on the optimization of the system performance and the environmental criteria. Some of the important properties of the backfill material have been identified [11] and are shown in Figure 1. The determination of the thermal conductivity of the backfill material can be carried out using the Thermal Needle Probe Device TP02 manufactured by Hukseflux Corporation. Furthermore, there is no specific method for determining the thermal conductivity of the backfill material admixture. The workability of the fresh admixture is among the important factors in pumping backfill material during the installation process. Furthermore, an effective means of avoiding interactions among pipes, the surrounding soil, and overlying aquifers is a lower permeability backfill 
material. Due to the various conditions during the operation of a GHE, the backfill material may be subject to significant changes in the state of stress. The sealing capacity and water tightness of the backfill material may be at risk when it does not succeed in reducing stress variations. Therefore, minimum strength should be considered carefully. However, there are no specific criteria in existing guidelines for the backfill material strength.

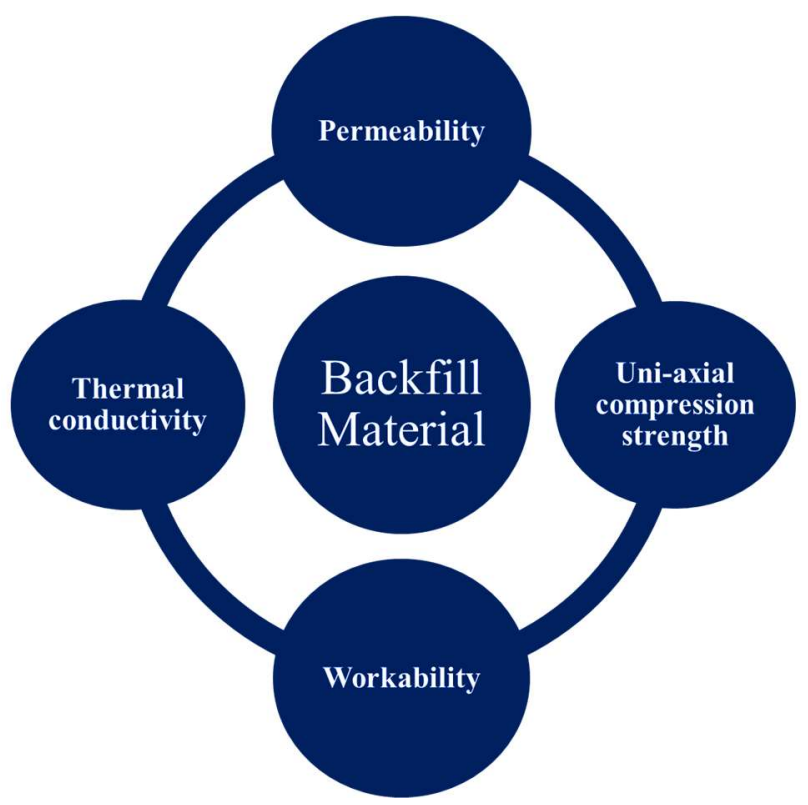

Figure 1. Most influential properties of backfill material on ground heat exchanger (GHE) performance.

As noted earlier, this study focused on the English-language literature and this approach is based on the work of others. In fact, the data covered in this study are not from all the articles published in the last eight years, but rather from a subset based on specific criteria (i.e., English-language papers published in reputable journals). These articles were published by authors from numerous countries. The results may, as a consequence, have some corresponding limitations, but these are likely to be minor. For example, the effect on citation rate of using languages other than English in scientific publications was analyzed recently by Di Bitetti and Ferreras [25]. They found that there is a tendency for non-native English scientists to publish exclusively in English and that articles published in English have a higher number of citations than those published in other languages, when the effect of journal, year of publication, and paper length are statistically controlled. The authors felt that this may be because articles in English are accessible to a larger audience. Another study, by Guerrero-Bote and Moya-Anegón [26], demonstrated that it is difficult to gather non-English-language articles. They showed that part of the citation impact of non-English-language journals seems to be invisible to Scopus, which makes the number of downloads proportionately greater than the citations. An examination of the correlation between downloads and citations in non-English-language journals indicated that if one wants to predict the citation rate for these titles, it will be difficult to use download data to do so. However, it is acknowledged that omitting non-English-language papers can lead to some biases. For instance, in a comparative evaluation of national research systems, Van Leeuwen et al. [27] have shown that care must be taken in interpreting bibliometric data, and it was concluded that the value of impact indicators of research activities at the level of an institution or a country strongly depend upon whether one includes or excludes research publications in Science Citation Index (SCI)-covered journals written in other languages than English.

Among the review articles on parameters affecting GHE performance published over the past eight years, only two discuss types of backfill materials, even though the importance of these materials is significant. Zhao et al. [28] studied effective methods for increasing the heat transfer of GHEs, mainly via a summary of advances in phase change materials (PCMs). Noorollahi et al. [29] investigated 
important parameters for the operation of GHEs. They provide some explanations about conventional backfill materials, and suggest that PCMs should be used to improve the performance of GHEs. Generally, however, no review has yet been published exclusively on the kinds of backfill materials used in GHEs, and this article is intended to address this need. The objective of this article is to provide a comprehensive review of a variety of types of backfill materials and their effects on GHE performance. For organizational purposes, the backfill materials are divided into two categories: conventional backfill materials (pure and mixed materials) and modern backfill materials (improved PCMs). Both categories are described in detail.

\section{Conventional Backfill Materials}

\subsection{Pure Materials}

Among the materials used for backfill, some are pure materials. The replacement of quartz sand with clay as a backfill material resulted in a 30\% reduction in the thermal resistance of the borehole [30]. Borehole space fills often use sand or gravel to enhance the thermal contact between the vertical GHEs and the ground, as well as to prevent the collapse of the borehole and the combination of groundwater and aquifer water [31]. Cementitious backfill materials have often been used in dry soil, since bentonite-based backfill materials are subject to shrinkage and desiccation [32].

According to previous investigations, the choice of conventional pure backfill material mainly focuses on cementitious [18] and sand soil [33] types. The thermal conductivity range of pure backfill material varies from 0.8 to $2.4 \mathrm{~W} / \mathrm{m} . \mathrm{K}$ [11]. Figure 2 shows the influence of the backfill material thermal conductivity on the size of the GHE. According to this figure, the total GHE length decreases with increasing backfill material thermal conductivity. In fact, the effect of backfill material thermal conductivity on reducing GHE length is higher in double U-tube compared to single U-tube GHEs. Furthermore, it can be seen that a single U-tube De25 (outer diameter of $25 \mathrm{~mm}$ ) and a double U-tube De32 (outer diameter of $32 \mathrm{~mm}$ ) have the lowest and highest total GHE length reductions, respectively. It is further observed in this figure that GHEs with large pipe diameters are more affected by variations in backfill material thermal conductivity compared to GHEs with small pipe diameters.

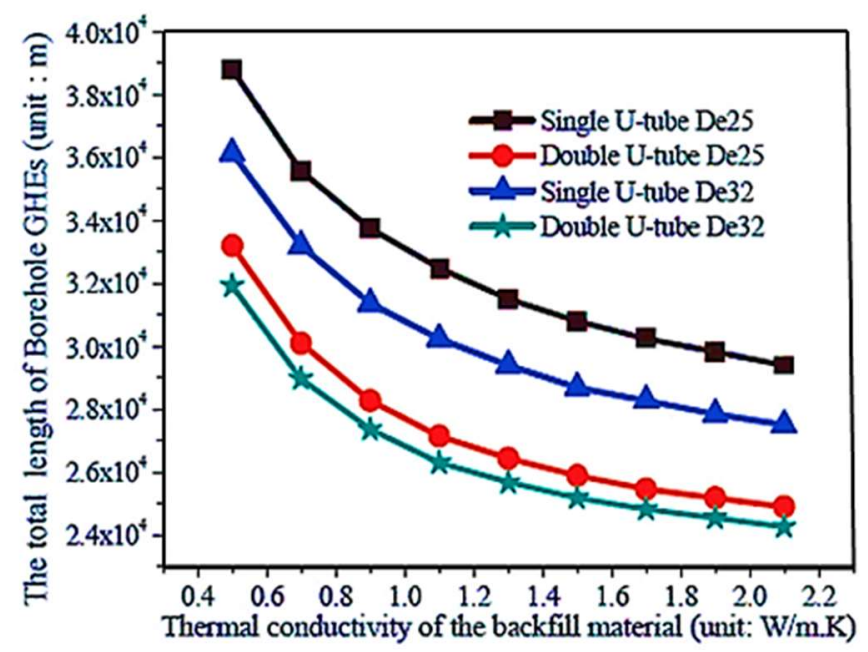

Figure 2. Influence of backfill material thermal conductivity on GHE size [13]. (Reprinted from Zhang, Wenke, Hongxing Yang, Lin Lu, and Zhaohong Fang. "Investigation on influential factors of engineering design of geothermal heat exchangers." Applied Thermal Engineering 84 (2015): 310-319. Copyright (2015), with permission from Elsevier).

Alberti et al. [34] compared three backfill materials, including ground (case 1), backfill material with a high thermal conductivity equal to that of the surrounding soil (case 2), and backfill material with a low thermal conductivity (case 3). The corresponding thermal conductivities for these cases 
are $2.3 \mathrm{~W} / \mathrm{m} . \mathrm{K}, 2.3 \mathrm{~W} / \mathrm{m} . \mathrm{K}$ and $0.7 \mathrm{~W} / \mathrm{m} . \mathrm{K}$, respectively. It should be noted that cases 2 and 3 have the same volumetric water content of the porous medium and hydraulic conductivity of the backfill material, with values of 0.2 and $5 \times 10^{-11} \mathrm{~m} / \mathrm{s}$, respectively. These are different from the corresponding values for case 1 of 0.35 and $2 \times 10^{-4} \mathrm{~m} / \mathrm{s}$, respectively. The variation of the heat exchange rate between the GHE and the surrounding soil with time, starting at the beginning of the winter season, is shown in Figure 3 for various backfill materials and Darcy velocities. The backfill material with high thermal conductivity (cases $2 a, 2 b, 2 c$ ) exhibits better energy performance than the backfill material with low thermal conductivity (cases $3 a, 3 b, 3 c$ ), respectively. The results were similar when comparing case $1 \mathrm{a}$ with zero velocity of underground water, and cases $3 \mathrm{c}$ and $1 \mathrm{c}$ with high velocity of underground water, to a low thermal conductivity of backfill material (case 3a). In addition, the authors examined the total variation of seasonal energy extracted from the ground for different backfill materials and Darcy velocities. The results show that, in cases 1 and 2, for example, for a relatively low thermal resistance of the borehole, the Darcy velocity significantly affects the performance of the GHE. At a Darcy velocity of $10^{-5} \mathrm{~m} / \mathrm{s}$, the seasonal energies of case 2c, case 3c, and case 1c increase by $97 \%, 73 \%$, and $100 \%$, respectively, compared to the zero groundwater velocity case [34]. In accordance with Table 1, various types of pure materials are used as backfill material in both heating and/or cooling modes. It can be seen that, among these materials, some are only used in the heating mode, such as saturated sand and protoplasm. The rest of the pure backfill materials in this table are usable in both operation modes.

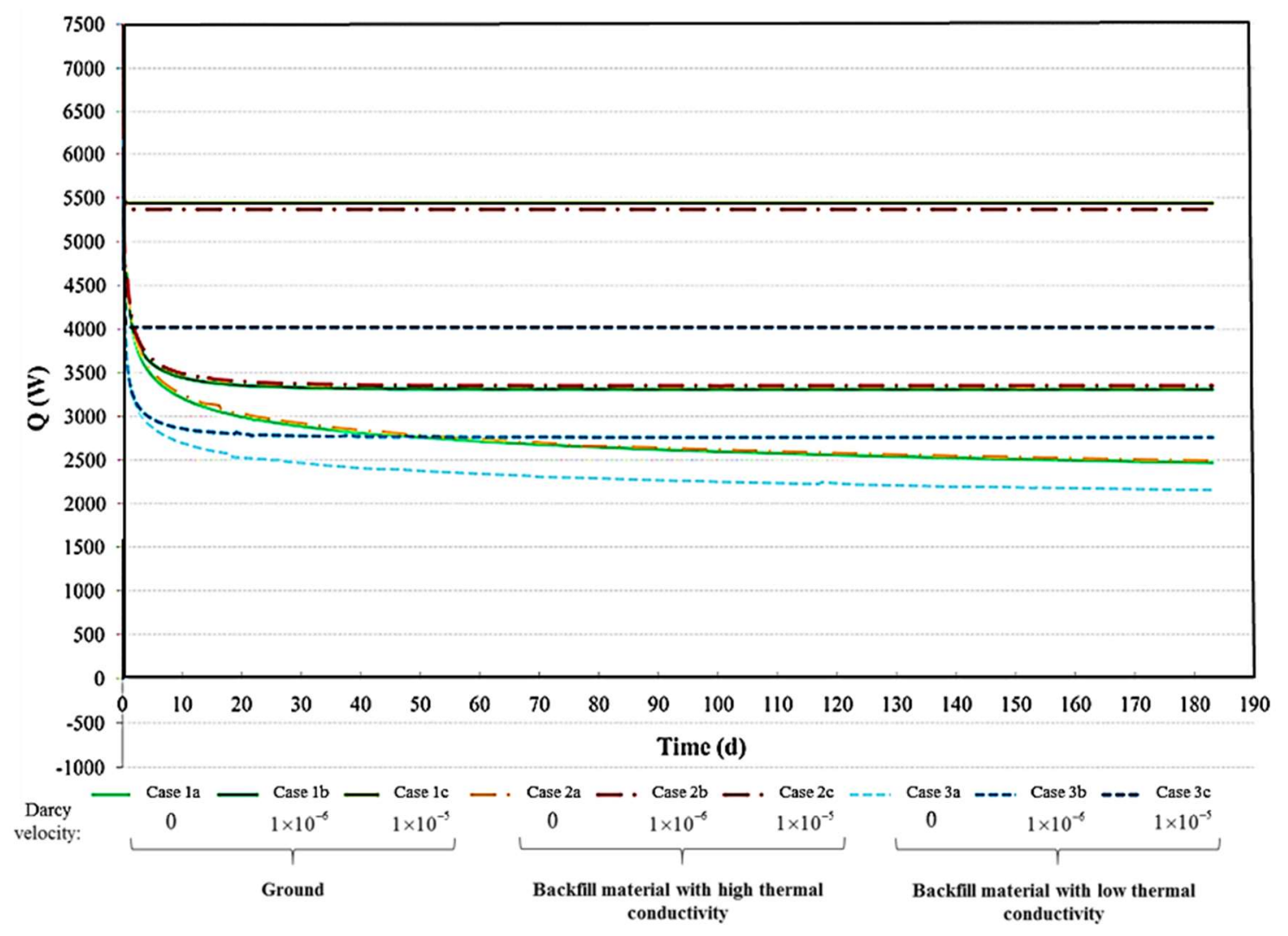

Figure 3. Heat exchange rate $(Q)$ between GHE and surrounding soil based on time for various backfill materials and Darcy velocities [34]. (Reprinted from Alberti, Luca, Adriana Angelotti, Matteo Antelmi, and Ivana La Licata. "A numerical study on the impact of grouting material on borehole heat exchangers performance in aquifers." Energies 10 (2017): 703-718. Copyright (2017), with permission from Multidisciplinary Digital Publishing Institute (MDPI)). 
Table 1. Usage of conventional backfill materials (pure materials) for primary operation modes.

\begin{tabular}{cccccccccc}
\hline \multirow{2}{*}{$\begin{array}{c}\text { Operation } \\
\text { Mode }\end{array}$} & Bentonite & $\begin{array}{c}\text { Saturated } \\
\text { Sand }\end{array}$ & $\begin{array}{c}\text { Conventional Backfill Material (Pure Material) } \\
\text { (Coarse/Fine) }\end{array}$ & $\begin{array}{c}\text { Sand } \\
\text { Sand }\end{array}$ & Protoplasm & Gravel & Soil & $\begin{array}{c}\text { Quartz } \\
\text { Sand }\end{array}$ & Clay \\
\hline Heating & $\sqrt{ }$ & $\sqrt{ }$ & $\sqrt{ }$ & $\sqrt{ }$ & $\sqrt{ }$ & $\sqrt{ }$ & $\sqrt{ }$ & $\sqrt{ }$ & $\sqrt{ }$ \\
\hline Cooling & $\sqrt{ }$ & & $\sqrt{ }$ & $\sqrt{ }$ & & $\sqrt{ }$ & $\sqrt{ }$ & $\sqrt{ }$ & $\sqrt{ }$ \\
\hline
\end{tabular}

\subsection{Mixed Materials}

In this section, descriptions are provided about mixed materials that are based on pure materials and used as backfill materials in GHEs. In order to optimize the performance of GHEs, a mixture of bentonite, crushed concrete, and water with a high specific heat capacity can be used [35]. Utilization of the sensible heat of bentonite is possible because of its density and moisture content, and can improve the GSHP efficiency [35]. Mainly in the United States until 2000, bentonite and concrete mixtures were used alone, with thermal conductivities of $0.75-0.80 \mathrm{~W} / \mathrm{m} . \mathrm{K}$ and $0.80-0.87 \mathrm{~W} / \mathrm{m} . \mathrm{K}$, respectively [21]. Of course, the high porosity and water reduction in such backfill materials decreases their thermal conductivities. Standard bentonite backfill material and enhanced bentonite-cement sand mix were compared by Smith and Perry [22]. Carlson [36] also made a comparison of such materials. Their results indicated that the use of enhanced bentonite-based backfill material can permit a reduction in the total borehole length by $10 \%$. A combination of backfill material with graphite or silica sand was examined by Lee et al. [9]. Based on their results, the thermal conductivity of the backfill material increases by adding more graphite and can reach up to $3.5 \mathrm{~W} / \mathrm{m}$.K. Delaleux et al. [8] used compressed expanded natural graphite as additives for backfill materials in order to increase their thermal conductivities. The results showed that the addition of such material leads to an increase in thermal conductivity of up to $5 \mathrm{~W} / \mathrm{m}$.K. It should also be taken into account that the backfill material thermal conductivity is reduced $1 \mathrm{~W} / \mathrm{m} . \mathrm{K}$ by each $10 \%$ reduction in water content by weight. According to Table 2, there are various types of mixed materials that can be used as backfill materials in GHEs for the operation modes. Most of these materials have been used as backfill materials only in heating or cooling modes. However, there are six materials that are used in both of operation modes: bentonite-cement, admixture of bentonite and quartzite, admixture of bentonite and water, cement, concrete, and sand-E-plug admixture. 
Table 2. Usage of conventional backfill materials (mixed materials) for primary operation modes.

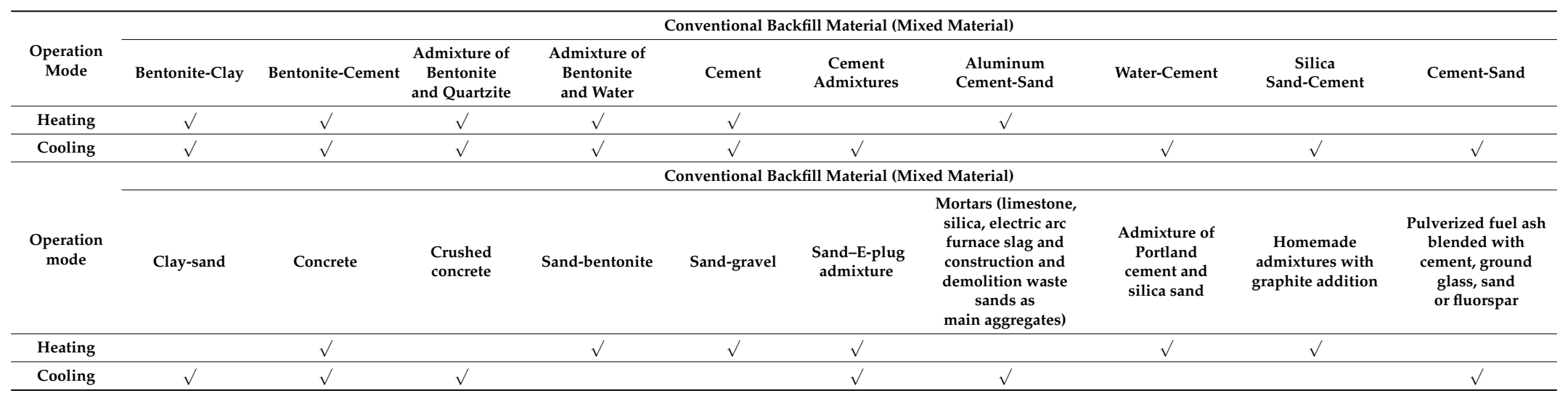


The effect of aggregate type and superplasticizer on the mechanical, rheological, thermal, and hydraulic properties of the cement-sand-based mortars was studied by Allan and Philippacopoulos [37]. The results indicate that the thermal conductivity of the cement-sand-based mortar increases from 1.67 to $2.42 \mathrm{~W} / \mathrm{m}$.K relative to super plasticized cement-sand-based mortar. By the late 1980s, mixed materials that were used as backfill materials were granular bentonite-water mixes [38]. Since the thermal conductivity range of these mixtures is relatively low (from 0.65 to $0.9 \mathrm{~W} / \mathrm{m} . \mathrm{K}$ ), Remund and Lund [39] combined bentonite with various additives (masonry sand, limestone, quartzite, etc.) and it was concluded that an increase of up to $100 \%$ in the thermal conductivity of these mixtures can be achieved. Remund and Lund also investigated the thermal conductivity of cementitious backfill material containing various fillers, including alumina grit, steel grit, silicon carbide, and silica sand. The results showed that adding conductive fillers and reducing the water/cement ratio in backfill material increases its thermal conductivity. Over the past decade, mostly graphite-based admixtures have been used to increase the thermal conductivity of backfill materials. In another study, the addition of graphite and silica sand to bentonite backfill material was examined [9]. The results showed that increasing the additive material led to an increase in mixture thermal conductivity and, at the same time, an increase in its viscosity. Due to mechanical and thermal behaviors as well as costing aspects, the use of a mixture of $5 \%$ natural flake graphite was considered by Erol and François [40]. One of the problems of bentonite-based backfill material is its low thermal conductivity and, because of its moisture dissipation, it is prone to cracking and shrinking [20]. For this reason, research on the development of cementitious backfill material that has a high thermal conductivity has been carried out. In addition, in order to increase the thermal conductivity of bentonite and cement-based backfill materials, silica sand is often used as an additive. In general, in order to improve the thermal conductivity of cement-based backfill material, various combinations have been used. According to $\mathrm{Xu}$ and Chung [41], in relation to the mixing of sand and cement, the thermal conductivity of such a mixture increases by $22 \%$ compared to cement. Other research has shown that pulverized fuel ash (PFA) can be used as a backfill material. It has good rheological properties, including high hydraulic conductivity, low shrinkage and workability as well as relative abundance. This substance is made from water, PFA and Portland cement reactions. However, the utilization of this material as a backfill has been minor [8,9,41]. Various additives such as cement, coarse/find sand, fluorspar, and ground glass have been used to increase the thermal conductivity of PFA backfill materials. It was shown that using fluorspar or coarse sand, compared with using ground glass or fine sand, led to a greater increase in the PFA backfill material thermal conductivity. Moreover, the authors concluded that by combining coarse ground glass and fluorspar, a good increase in the PFA backfill material thermal conductivity could be achieved. Bentonite/graphite $(0-95 \% \mathrm{wt})$ composites and bentonite/sand $(0-50 \% \mathrm{wt})$ composites were investigated by Jobmann and Buntebarth [42]. A significant increase in the thermal conductivity of the backfill material, up to $11.5 \mathrm{~W} / \mathrm{m} . \mathrm{K}$, was observed when using the highest graphite content ( $95 \% \mathrm{wt})$. However, at the graphite content of $15 \% \mathrm{wt}$, the thermal conductivity decreased to $1.9 \mathrm{~W} / \mathrm{m} . \mathrm{K}$. Seven types of bentonite backfill material were studied by Lee et al. [9], by adding graphite or silica sand. They added 5 to $30 \% \mathrm{wt}$ graphite or 15 to $60 \% \mathrm{wt}$ silica sand to $20 \% \mathrm{wt}$ and $30 \% \mathrm{wt}$ bentonite mixtures. The results show that adding $30 \%$ wt silica sand to a raw bentonite backfill material with a thermal conductivity of $0.8 \mathrm{~W} / \mathrm{m} . \mathrm{K}$ leads to a thermal conductivity of up to $1 \mathrm{~W} / \mathrm{m} . \mathrm{K}$, while adding the same amount of graphite results in a thermal conductivity of up to $3 \mathrm{~W} / \mathrm{m}$.K. Adding such materials to $20 \% \mathrm{wt}$ bentonite mixture leads to a critical increase in the viscosity of the backfill material. Generally, according to research carried out by researchers, it can be concluded that one of the most effective additives to increase the thermal conductivity of bentonite is graphite. Of course, it should be taken into account that achieving high thermal conductivity using a graphite results in a significant increase in the cost and viscosity of the backfill material [8].

According to Remund and Lund [39], because the thermal conductivity of bentonite-based backfill material is relatively low, materials such as sand should be used to improve its thermal 
conductivity. The performance of a geothermal system when adding sand to a cement-bentonite-based backfill material was studied by Desmedt et al. [43]. They concluded that this measure improves the performance of the system. Furthermore, homemade admixtures containing natural graphite flakes that are prepared in a laboratory and tested in a $1 \times 1 \times 1 \mathrm{~m}^{3}$ sandbox under, successively, dry sand and fully water saturated sand conditions are also employed as backfill materials [11]. Due to the high absorption of water in graphite, in homemade admixtures the amount of graphite powder is kept at $5 \%[11,37,44]$. According to a comparison between homemade backfill materials and other types, the compressive strength, permeability, and density are at acceptable limits. Although the flow ability of bentonite-based materials is very good, in some of the homemade admixtures and silica sand-based backfill materials, due to the no-flow condition of materials or slow efflux time, there may be some problems during the pumping process of the backfill material. In fact, due to the good hydraulic permeability and compression strength as well as the relatively low cost of homemade admixtures, they can be used as suitable backfill materials. In addition, the other main constituents that can be used in mortars are silica sand, limestone, electric arc furnace slag, and construction and demolition waste. In Spain, silica sand and limestone are natural constituents. The Global Steel Wire Company located in Santander, Cantabria, Spain, has a side product of electric arc furnace slag [45-47]. This material can also be obtained from a crushed concrete recycled aggregate plant. It should be noted that the thermal conductivity of cement was increased after mixing with the four above-mentioned constituents. The maximum thermal conductivities of the mortars based on limestone, construction and demolition waste, as well as electric arc furnace slag and silica sand are $1.8 \mathrm{~W} / \mathrm{m} . \mathrm{K}, 1.3 \mathrm{~W} / \mathrm{m} . \mathrm{K}, 1.5 \mathrm{~W} / \mathrm{m} . \mathrm{K}$, and $2.1 \mathrm{~W} / \mathrm{m} . \mathrm{K}$, respectively. In general, by using silica sand, limestone, construction and demolition waste, and electric arc furnace slag mortars, the borehole depth is reduced by $18 \%, 16 \%, 9 \%$, and $12 \%$, respectively, compared to the cement reference material [48]. It is expected that there would be some changes in the amount of backfill material moisture after pumping into the borehole, and then that the amount of moisture would become constant due to achieving a balance between moisture levels and ground local temperature. Among the studies on the thermal conductivity of backfill materials used in GHEs, ground property variations per meter of borehole depth are not taken into account, even though water content in the ground is not constant along the borehole [8]. Figure 4 shows the influence of water content on the thermal conductivity of bentonite/graphite composites and bentonite. According to this figure, the thermal conductivity in both composites changes linearly, which indicates the significant influence of the water content on the thermal conductivity of the composites. The results show that the thermal conductivity of backfill material containing graphite is much higher than that for the pure material. In the case of a change in the water content of $10 \% \mathrm{wt}$, the thermal conductivity changes in the range of $1 \mathrm{~W} / \mathrm{m} . \mathrm{K}$ [8]. Therefore, the amount of water in bentonite and its composites plays an important role in the thermal conductivity. A usage breakdown of mixed and pure backfill materials in GHEs is shown in Figure 5. It is seen that bentonite is the most widely used backfill material in GHEs (about 17\%), followed by silica sand and coarse/fine sand (both at $10 \%$ ). It is also observed that concrete backfill materials $(7 \%)$ and bentonite and water mixture $(7 \%)$ are widely used. Interestingly, the number of studies that have been conducted on the use of soil as backfill material in GHEs is relatively high (about $5 \%$ ) over the past eight years. It is noted that, among conventional backfill materials that are used in GHEs, pure materials are more often considered by researchers than mixed ones. 


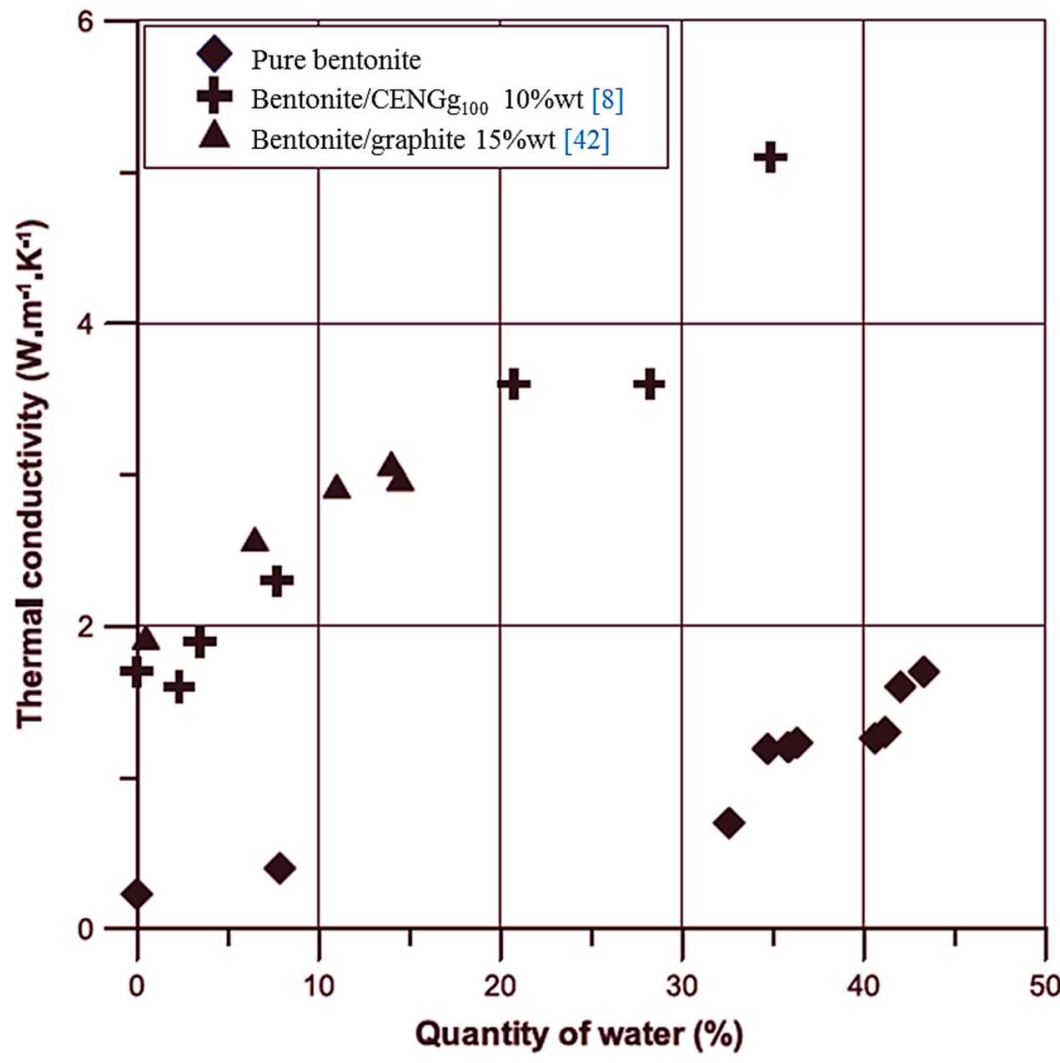

Figure 4. Influence of water content on the thermal conductivity of bentonite and bentonite/graphite composites [8]. (Reprinted from Delaleux, Fabien, Xavier Py, Regis Olives, and Antoine Dominguez. "Enhancement of geothermal borehole heat exchangers performances by improvement of bentonite grouts conductivity." Applied Thermal Engineering 33 (2012): 92-99. Copyright (2012), with permission from Elsevier).

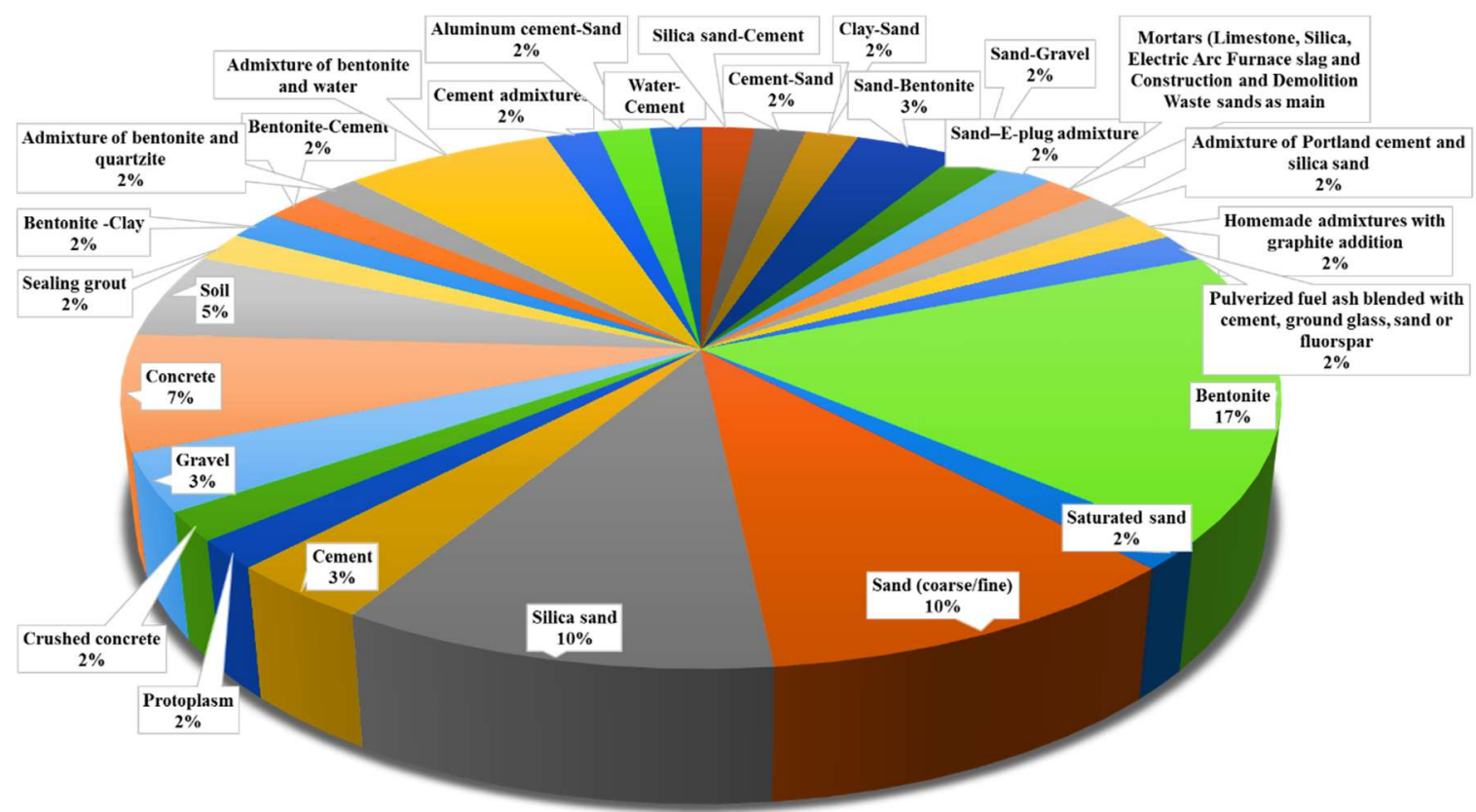

Figure 5. Usage breakdown of mixed and pure backfill materials in GHEs from 2010 to 2018. 


\section{Modern Backfill Materials}

\subsection{Introduction}

Recently, the benefits of combining PCMs and GSHPs has attracted a great deal of attention. Because PCMs store energy in the form of latent heat, they have a higher energy density, making them useful for high-density energy storage. Latent heat during the phase change is absorbed or liberated. In the process of solidification and melting, the PCM temperature is constant, which improves GSHP performance. Moreover, by using a PCM as a backfill material, it is possible to reduce the temperature variation in the surrounding soil, which effectively reduces the need for ground and borehole space. These results were verified by Weibo et al. [49]. Nonetheless, limited research has been done on the use of PCMs in GHEs. PCMs are used in aerospace, buildings, military industries, and other fields. Furthermore, one of the most important issues in using various backfill materials is examining the possibilities of heat recovery at different operating and ambient conditions. Such a study was conducted by Kassai et al. [50] and provided more useful information for engineering practices compared to their past methods. A combination of PCM storage units with ground thermal energy storage systems was carried out by Rabin and Korin [51] in 1996 using a helical GHE; this was the first study on the application of PCMs in geothermal systems. By using PCMs instead of sand backfill materials, the soil temperature changes more slowly. Among the advantages of using PCMs as backfill materials in GSHP systems, having a small thermal radius as well as a constant temperature during phase change results in reducing the distances between multiple GHEs in one area. As mentioned earlier, the use of a PCM can reduce the need for ground space, which also reduces instantaneous heating or cooling waves in the ground [52]. Kong et al. [53] used PCMs as backfill materials in GHEs. Moreover, the superiority of PCMs compared to conventional backfill material was confirmed by Weibo et al. [49]. In intermittent operation, the use of a PCM as a backfill material was suggested because it can be returned quickly to its original state. Wang et al. [54] also used a PCM as a backfill material. The utilization of PCMs in horizontal GHEs and at lower depths as a backfill material was examined by Bottarelli et al. $[55,56]$. The results indicated that the heat pump coefficient of performance (COP) increased through the use of PCMs. According to studies by Lei and Neng [57], when a fixed energy demand is applied, the use of a PCM as a backfill material can reduce the number of required boreholes. An investigation on utilizing PCMs in vertical GHE was performed with a mathematical model by Weibo et al. [49]. The results showed that the area affected by GHE operation can be reduced through the use of PCMs.

A PCM storage tank was used in a GSHP system $[58,59]$. The goals were to prevent greenhouse freezing in the winter season, to investigate the impact of the PCM on the GSHP, and to study the heat storage properties of the PCMs. The addition of two phase change heat storage reservoirs to a GSHP system was examined by Real et al. [60]. They used the first reservoir for cooling the PCM, with the low temperature being that of the outdoors during the night. The storage then decreased the temperature of the building during hot days. The second reservoir was used as an alternative for dissipating the heat at a constant temperature, which resulted in an increase in the system COP. In fact, the more independent the system is of the outside temperature, the higher its efficiency. Furthermore, Moreno et al. [61] used a PCM as a heat energy storage tank in a heat pump system. Dehdezi et al. [62] used microencapsulated PCMs in a horizontal GHE. The results showed that the surrounding soil temperature variation can be reduced by up to $3{ }^{\circ} \mathrm{C}$ by using such PCMs compared to conventional backfill material. Bottarelli et al. $[52,55,63]$ used encapsulated PCMs in GHEs as backfill material. One of the advantages of using PCMs in geothermal systems is the provision of compact seasonal underground thermal energy storage (UTES) [56].

Despite the widespread use of organic PCMs in engineering projects, these materials have some problems [64]. The thermal conductivity of organic PCMs is low $(0.235 \mathrm{~W} / \mathrm{m} . \mathrm{K})$. Furthermore, the phase change process which occurs in these materials is in the form of solid-liquid. Therefore, when the phase is liquid, there is the possibility of leaking PCM into the borehole and subsequently 
affecting heat transfer. In addition, the surrounding soil can be harmed. In order to enhance the thermal conductivity of PCMs, developed graphite, carbon fiber, and some high thermally conductive metal compounds have been used as additives to PCMs. In order to avoid the consequences of leaking PCMs, two methods were recently developed, including the use of the microencapsulation of PCMs and fostering PCM reactions with other materials such as silica and polyethylene to produce shape-stabilized PCMs (SSPCMs).

\subsection{Improved PCMs as Backfill Materials}

Due to the fact that most PCMs suffer from a common problem of low thermal conductivity, methods have been employed to increase it [65]. In addition, options are needed to address the leaking of these materials into the borehole. Interestingly, according to Table 3, it can be seen that improved PCMs were applied only in the cooling operation mode of geothermal heat pumps.

Table 3. Usage of modern backfill materials (improved phase change materials (PCMs)) as backfill material for primary operation modes.

\begin{tabular}{cccccc}
\hline $\begin{array}{c}\text { Operation } \\
\text { Mode }\end{array}$ & $\begin{array}{c}\text { Microencapsulated } \\
\text { PCM }\end{array}$ & $\begin{array}{l}\text { Shape-Stabilized } \\
\text { PCM (SSPCM) }\end{array}$ & Acid & $\begin{array}{c}\text { Enhanced } \\
\text { Acid }\end{array}$ & Paraffin RT27 \\
\hline Cooling & $\sqrt{ }$ & $\sqrt{ }$ & $\sqrt{ }$ & $\sqrt{ }$ & $\sqrt{ }$ \\
\hline
\end{tabular}

\subsubsection{Shape-Stabilized PCM (SSPCM)}

A mixture of lauric and decanoic acids with mass concentrations of silica, decanoic acid, and expanded graphite of $10 \%, 60 \%$, and $6 \%$, respectively, forms a SSPCM. The latent heat and thermal conductivity of these materials are $109.2 \mathrm{~kJ} / \mathrm{kg}$ and $1.528 \mathrm{~W} / \mathrm{m} . \mathrm{K}$, respectively [64]. An example of such materials was prepared by $\mathrm{Li}$ et al. $[64,66]$. The heat exchange in a one-meter borehole filled with crushed concrete is $1 / 223$ times less than one filled with the SSPCM. In addition, the thermal influence radius of the crushed concrete is 0.9 times smaller than for the SSPCM [64]. Because the thermal conductivity is much higher for the SSPCM than the conventional backfill material, the efficiency of the GSHP system is improved. One of the storage problems of PCMs has been addressed in SSPCMs by keeping the phase change process stable. In general, in areas where underground water is not widely available, the use of a SSPCM is appropriate. Of course, in order to ensure a thermal radius reduction and stable operation for the GSHP system, a sufficient recovery time should be allowed for the SSPCM backfill material [67]. Figure 6 shows the influence of the SSPCM on the heat exchange rate per meter of borehole depth. Since heat pumps in engineering applications usually do not operate for more than $12 \mathrm{~h}$ in one day, the operation simulation was conducted for a 12-h period and in the cooling operation mode. According to Figure 6, the heat exchange per meter of borehole depth filled with SSPCM decreases with time from an initial value of $227.89 \mathrm{~W} / \mathrm{m}$ to $85.74 \mathrm{~W} / \mathrm{m}$, while for a borehole filled with crushed concrete backfill materials the heat exchange reduces from an initial value of $152.40 \mathrm{~W} / \mathrm{m}$ to $83.46 \mathrm{~W} / \mathrm{m}$. Moreover, the heat storage of SSPCM backfill material and crushed concrete was seen to be $2.63 \times 10^{5} \mathrm{~kJ}$ and $2.15 \times 10^{5} \mathrm{~kJ}$, respectively, indicating a $22 \%$ greater storage capacity for the SSPCM than the crushed concrete backfill material. Figures 7 and 8 show the influence of the SSPCM backfill material on the outlet temperature and the heat pump COP. The simulation results are again for $12 \mathrm{~h}$ of system operation. The outlet temperature of the GHE for SSPCM and crushed concrete backfill materials is $22.15^{\circ} \mathrm{C}$ and $23.98^{\circ} \mathrm{C}$, respectively, where the inlet temperature is $14.5^{\circ} \mathrm{C}$. From Figure 8, the heat pump COP of 6.34 at the beginning of operation is seen to decline to 5.41 and 5.12 using SSPCM and crushed concrete, respectively. It should be noted that the liquid fraction of the SSPCM at the end of operation (after running for $12 \mathrm{~h}$ ) is only $34 \%$. Thus, the advantages of SSPCMs on heat pump system efficiency become increasingly evident when the duration of heat pump operation is increased [64]. 


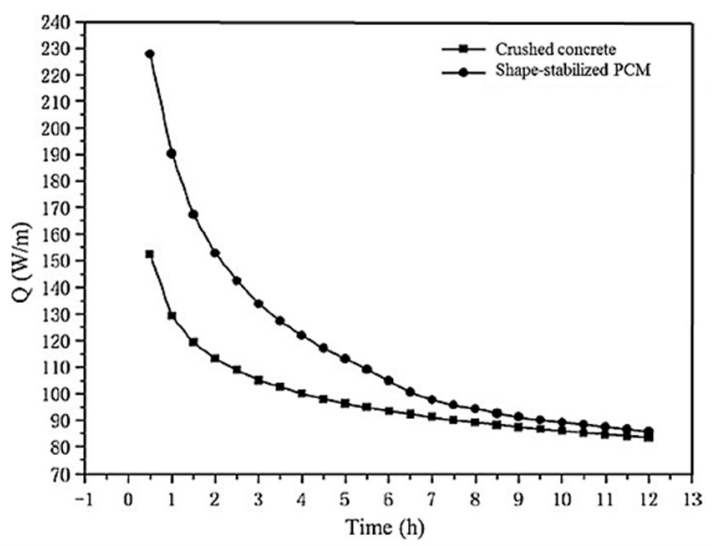

Figure 6. Influence of backfill material on the heat exchange rate $(Q)$ per meter of borehole depth, over a day [64]. (Reprinted from Li, Xiangli, Cang Tong, Lin Duanmu, and Liangkan Liu. "Study of a U-tube heat exchanger using a shape-stabilized phase change backfill material." Science and Technology for the Built Environment 23 (2017): 430-440. Copyright (2017), with permission from Taylor \& Francis Group).

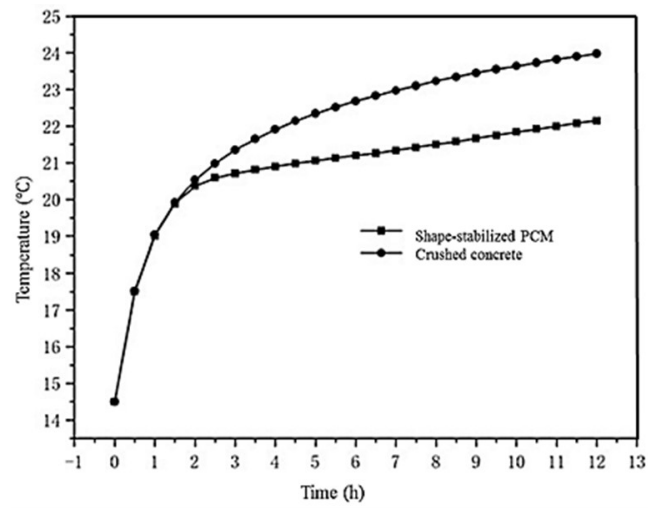

Figure 7. Influence of backfill material on outlet temperature of GHE, over a day [64]. (Reprinted from Li, Xiangli, Cang Tong, Lin Duanmu, and Liangkan Liu. "Study of a U-tube heat exchanger using a shape-stabilized phase change backfill material." Science and Technology for the Built Environment 23 (2017): 430-440. Copyright (2017), with permission from Taylor \& Francis Group).

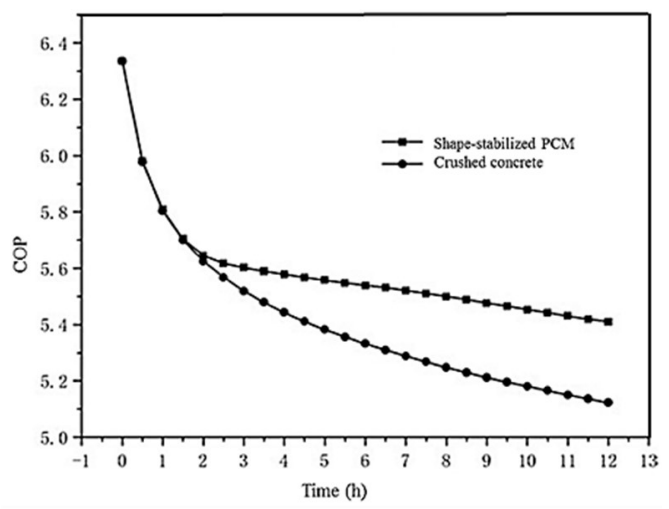

Figure 8. Influence of backfill material on heat pump COP, over a day [64]. (Reprinted from Li, Xiangli, Cang Tong, Lin Duanmu, and Liangkan Liu. "Study of a U-tube heat exchanger using a shape-stabilized phase change backfill material." Science and Technology for the Built Environment 23 (2017): 430-440. Copyright (2017), with permission from Taylor \& Francis Group).

The influence of different backfill materials on COP and accumulated electricity consumption of the heat pump during $24 \mathrm{~h}$ of continuous operation is shown in Figure 9a. In that figure, the three blue curves based on the left Y-axis show the influence of different backfill materials on COP, and the 
three red curves based on the right $\mathrm{Y}$-axis show the accumulated electricity consumption $(\mathrm{kWh})$ of the heat pump during $24 \mathrm{~h}$ of continuous operation. In all cases, it is observed that COP decreases with the increasing operating time, while decreasing ratios are attained for SSPCM backfill materials and conventional backfill materials, at $14.1 \%$ and $16.3 \%$, respectively. Furthermore, the COP with paraffin is decreased by $50.5 \%$ (from $6.22 \%$ to $3.08 \%$ ) after $24 \mathrm{~h}$ of operation. It should be noted that the power consumption, which is an important indicator in the evaluation of the heat pump system, strongly determines the operating costs of a system [67]. When paraffin is used as a backfill material, after $24 \mathrm{~h}$ of operation the accumulated electricity consumption of the heat pump reaches $18.7 \mathrm{kWh}$, which is 1.46 and 1.39 times of the accumulated electricity consumed by the heat pump with SSPCM and conventional backfill materials, respectively. Figure $9 \mathrm{~b}$ illustrates the influence of several backfill materials on the GHE efficiency. According to this figure, the highest efficiency (0.44) is obtained using SSPCM as a backfill material, which is 2.12 and 1.18 times the corresponding efficiency value for paraffin and conventional backfill materials, respectively. The influence of backfill materials in various daily operations on the thermal radius where soil thermal saturation occurs is shown in Figure 10 (soil thermal saturation refers to the situation when the difference between soil temperature at $x$ meters away from the borehole center and the initial temperature of the domain, divided by the initial temperature of the domain, becomes less than or equal to $0.5 \%$ [67]). The minimum thermal radius is obtained using SSPCM as the backfill material. Furthermore, the thermal radius for the conventional backfill material, when the intermittent ratio is equal to 2, is 1.056 and 1.055 times of the thermal radius for SSPCM and paraffin backfill materials, respectively. Generally, with a decrease in intermittent time, the thermal radius increases [67].

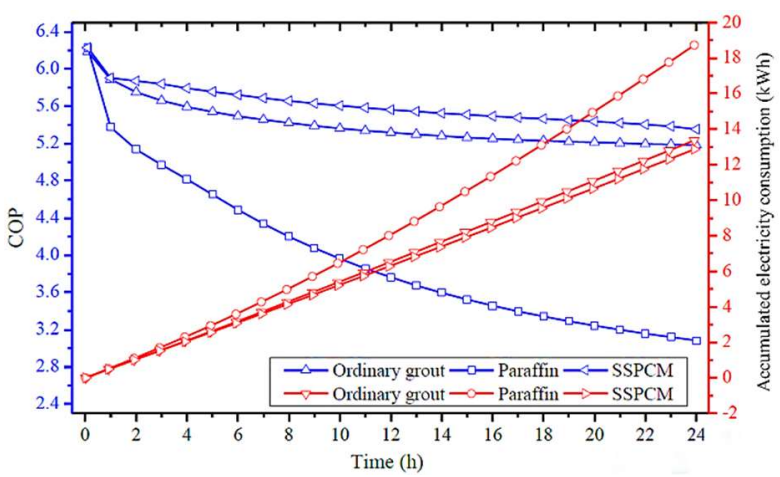

(a)

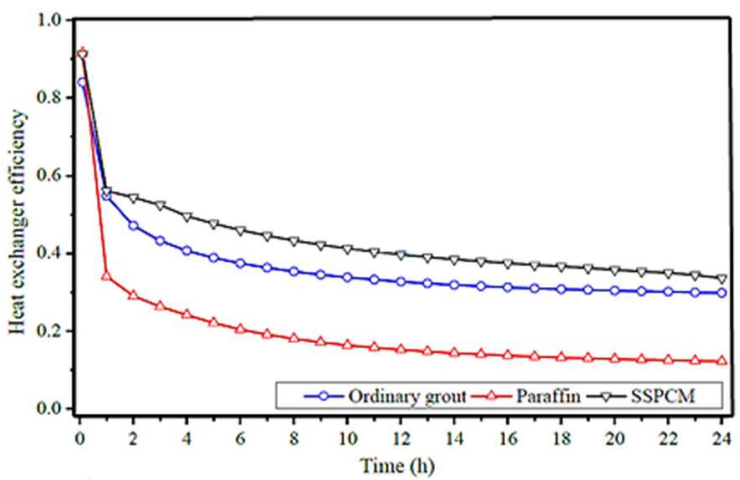

(b)

Figure 9. Influence of backfill materials on (a) COP and accumulated electricity consumption of heat pump, and (b) ground heat exchanger efficiency [67]. (Reprinted from Chen, Fei, Jinfeng Mao, Shangyuan Chen, Chaofeng Li, Pumin Hou, and Lu Liao. "Efficiency analysis of utilizing phase change materials as grout for a vertical U-tube heat exchanger coupled ground source heat pump system." Applied Thermal Engineering 130 (2018): 698-709. Copyright (2018), with permission from Elsevier). 


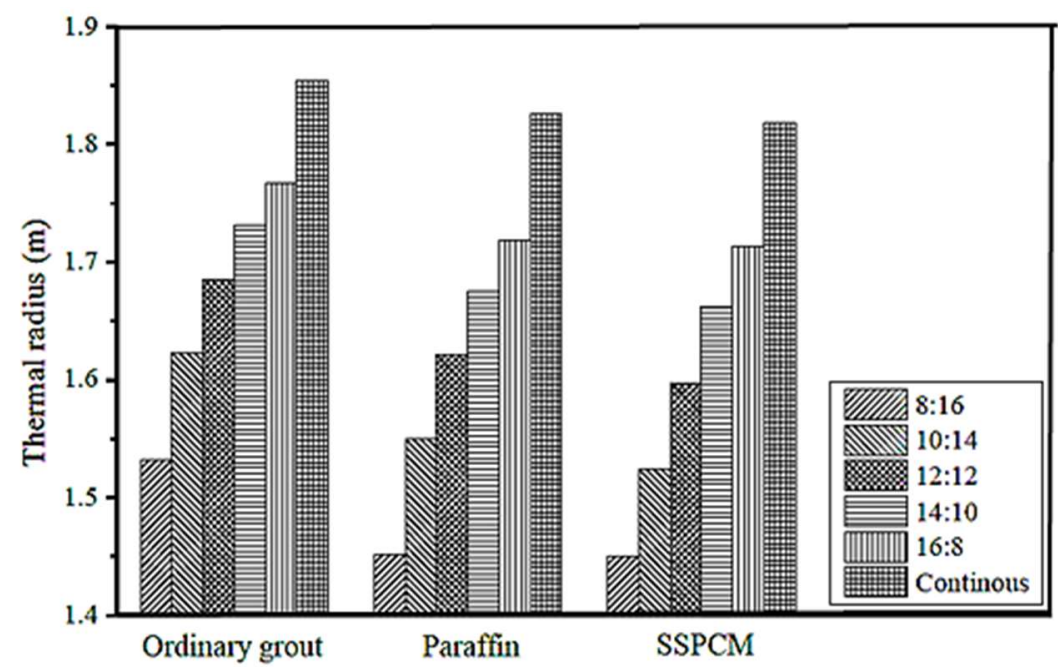

Figure 10. Influence of backfill materials in various daily operations on the thermal radius [67]. (Reprinted from Chen, Fei, Jinfeng Mao, Shangyuan Chen, Chaofeng Li, Pumin Hou, and Lu Liao. "Efficiency analysis of utilizing phase change materials as grout for a vertical U-tube heat exchanger coupled ground source heat pump system." Applied Thermal Engineering 130 (2018): 698-709. Copyright (2018), with permission from Elsevier).

\subsubsection{Paraffin RT27, Acid and Enhanced Acid}

Rubitherm Gmbh in Germany produces paraffin RT27 [68], which is a mixture of 35\% lauric and $65 \%$ capric acids [69]. An enhanced acid is also obtained by mixing metal particles with the acid to increase the thermal conductivity [54]. In Figure 11, the influences on the heat transfer rate and GSHP effectiveness are shown for four backfill materials: paraffin RT27, soil, enhanced acid, and acid. Figure 11a shows the variations of the heat exchange rate between the backfill material and the working fluid with time. Due to the heat transfer from the fluid to the soil and the subsequent increase in the temperature of the soil over time, the heat transfer rate is reduced. In addition, the temperature difference between the backfill material and the working fluid is also reduced. Because the heat transfer in the ground is mostly in the form of thermal conduction, by increasing the thermal conductivity the heat transfer rate is improved [55,70]. Since the acid and the paraffin RT27 below $3{ }^{\circ} \mathrm{C}$ are in the solid state and since the thermal conductivity is less for solid paraffin RT27 than solid acid, the paraffin RT27 heat transfer rate is less than that for the acid before $3 \mathrm{~h}$. Furthermore, since the thermal conductivities of liquid paraffin RT27 and liquid acid are the same, the heat transfer rates in both materials are similar after this time. Figure $11 \mathrm{~b}$ shows the variations of effectiveness for four backfill materials with time. In all four cases, the efficiency steadily decreases over time. The highest efficiency is observed for the soil, because of its higher thermal conductivity. Moreover, due to the higher thermal conductivity of enhanced acid compared with acid, a greater temperature difference was attained between the outlet and inlet pipes; therefore, the enhanced acid has a higher effectiveness than the acid. Furthermore, due to the higher phase change temperature and consequent higher efficiency, the paraffin RT27 has the highest effectiveness after the soil [70]. 


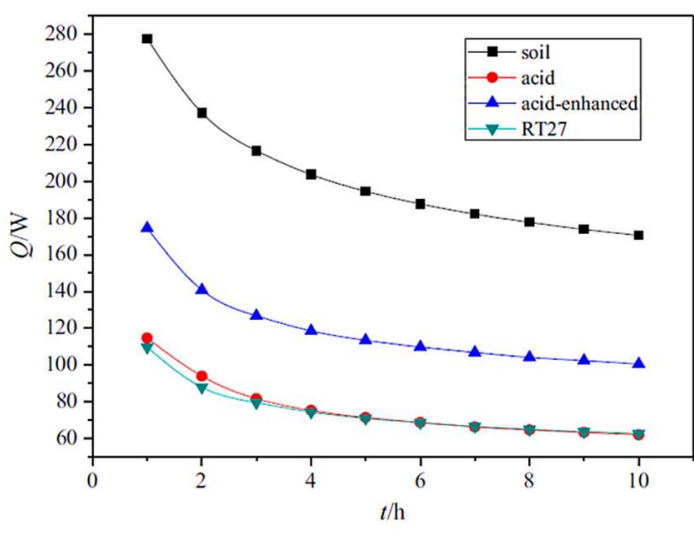

(a) Heat exchange rate

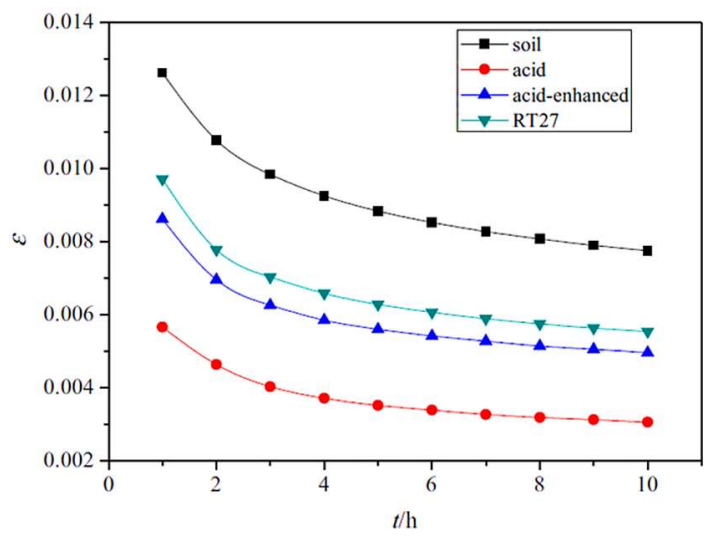

(b) Effectiveness

Figure 11. Influences of four backfill materials (paraffin RT27, soil, enhanced acid, and acid) on (a) heat exchange rate $(Q)$, and (b) ground-source heat Pump (GSHP) effectiveness $(\varepsilon)$ [70]. (Reprinted from Qi, Di, Liang Pu, Futao Sun, and Yanzhong Li. "Numerical investigation on thermal performance of ground heat exchangers using phase change materials as grout for ground source heat pump system." Applied Thermal Engineering 106 (2016): 1023-1032. Copyright (2016), with permission from Elsevier).

The dimensionless soil temperature variation with time for the two different backfill materials is shown in Figure 12. A greater effect of working fluid temperature on the soil is observed when the radial distance is smaller. Since the PCM temperature during the process of latent heat release remains constant, the surrounding soil temperature changes rapidly when using sand soil backfill material compared to mixed acid backfill material [71]. The mean fluid temperature variation with time for two backfill materials is shown in Figure 13. It is observed that changes in the mean fluid temperature during the use of acid mixture backfill material are much less than those during the use of the sand backfill material [71]. A general breakdown of the use of innovative methods for improving the organic PCM used in GHEs is presented in Figure 14. According to this figure, it can be seen that the acid and the SSPCM backfills are used the most among modern backfill materials for GHEs, at 30\% and $28 \%$, respectively. The other three modern backfill materials have the same usage frequencies, at $14 \%$. It should be noted that Figure 14 is based on the use of modern backfill materials (phase change materials) that have been studied numerically and experimentally over the past eight years, therefore data from both real applications in GHE installations and research works are used in this figure.

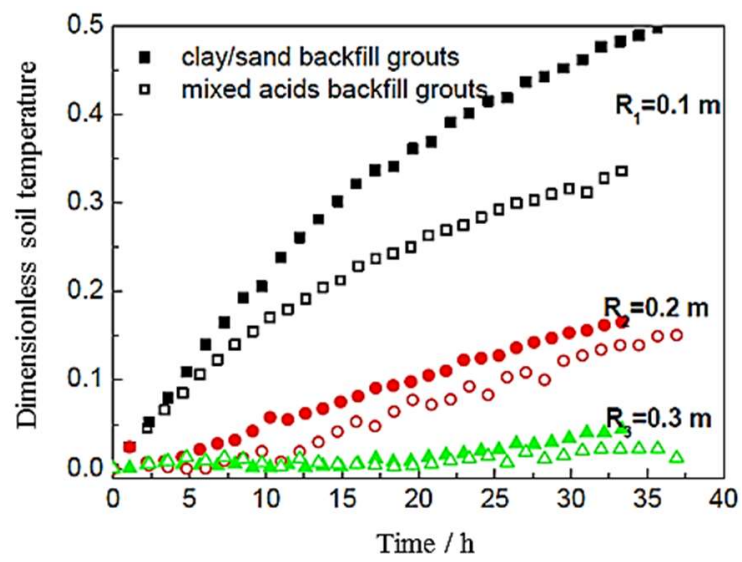

Figure 12. Variation of dimensionless soil temperature with time (h) for two backfill materials [71]. (Reprinted from Lei, Haiyan, and Chuanshan Dai. "Comparative experiment of different backfill grouts for concentric ground heat exchangers." Geothermal Resources Council Transactions 37 (2013): 597-600. Copyright (2013), with permission from Geothermal Resources Council (GRC)). 


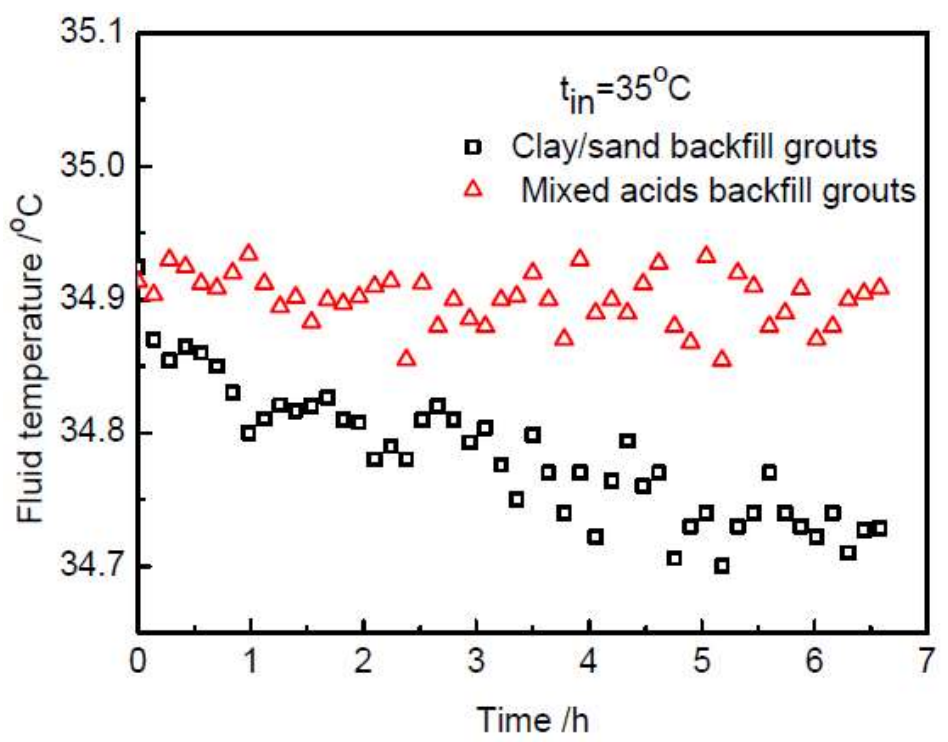

Figure 13. Variation of mean fluid temperature with time for two backfill materials [71]. (Reprinted from Lei, Haiyan, and Chuanshan Dai. "Comparative experiment of different backfill grouts for concentric ground heat exchangers." Geothermal Resources Council Transactions 37 (2013): 597-600. Copyright (2013), with permission from Geothermal Resources Council (GRC)).

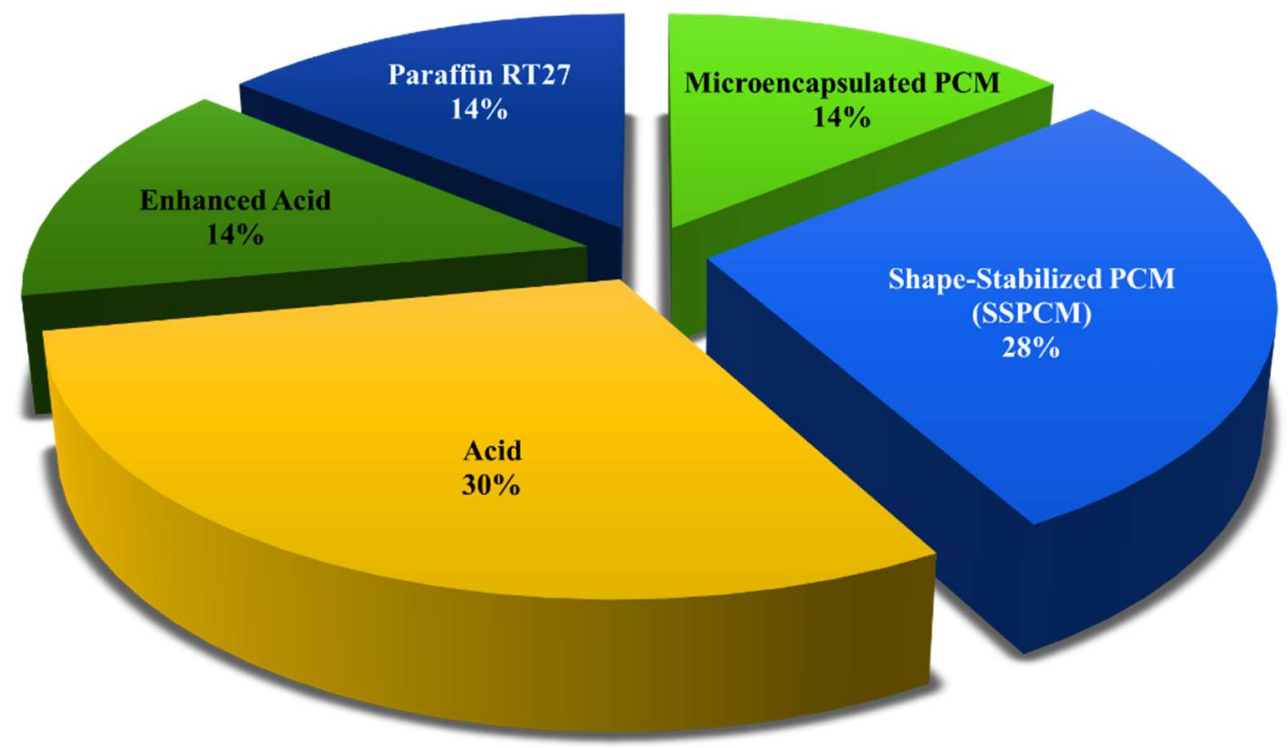

Figure 14. Usage breakdown of modern backfill materials in GHEs from 2010 to 2018.

In addition, according to Figure 15, conventional backfill materials are used more $(90 \%$ of instances) in GHEs than modern backfill materials (10\%). It is also clear from this figure that the rate of use of modern backfill materials that have been studied numerically $(86 \%)$ is higher than those that have been studied experimentally (14\%). Moreover, for conventional backfill materials, the proportions of numerical and experimental studies are $55 \%$ and $45 \%$, respectively, indicating that researchers have used both types of studies extensively. 


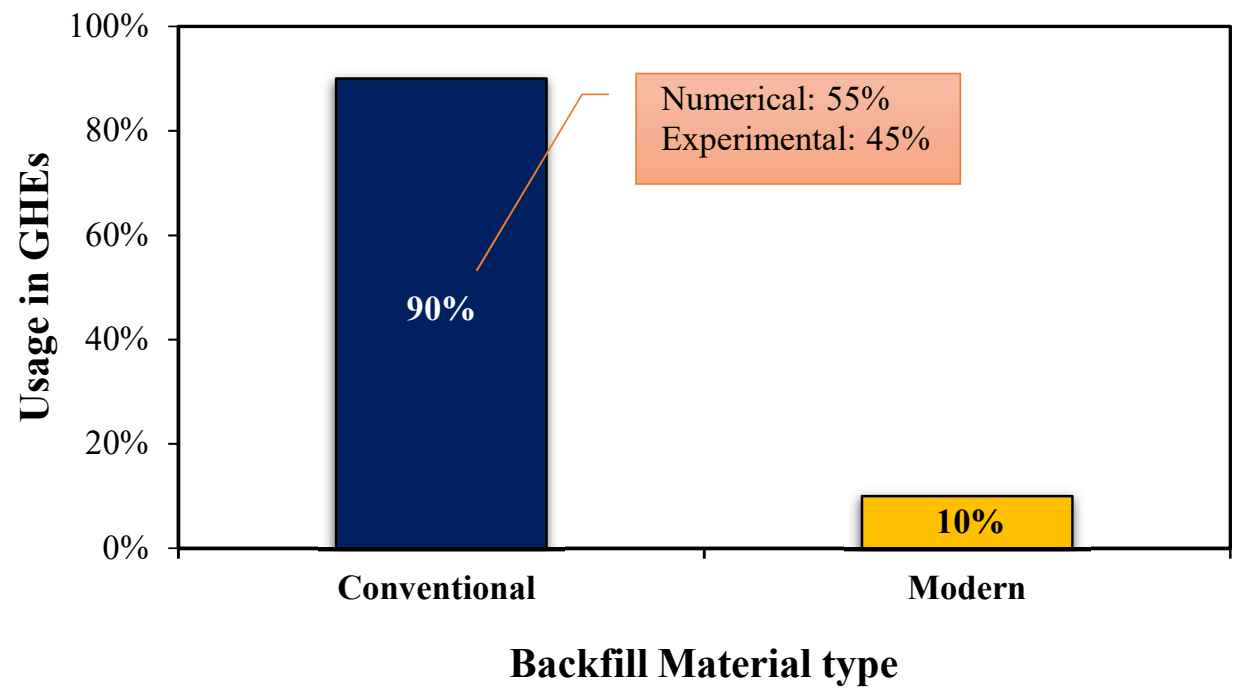

Figure 15. Usage breakdown of conventional and modern backfill materials in GHEs from 2010 to 2018.

\section{Conclusions}

Achieving environmentally friendly and more efficient energy utilization, as well as more sustainable power generation and building heating/cooling, can be supported by geothermal energy systems. Among the review articles on parameters affecting GHE performance published over the past eight years, only two discuss types of backfill materials, even though the importance of these materials is significant. The backfill material which fills the space between the pipe and the soil greatly affects the performance of GHEs. Therefore, in this article a comprehensive review of various types of backfill materials and their effects on GHE performance is provided. For convenience, backfill materials are divided into two categories: conventional backfill materials (pure and mixed materials) and modern backfill materials (improved PCMs). Both types are described in detail. The main conclusions are as follow:

1. Bentonite has been used considerably as a backfill material in GHEs (about $17 \%$ of the time) over the past eight years, followed by silica sand and coarse/fine sand, both at $10 \%$. Concrete backfill materials $(7 \%)$ and a mixture of bentonite and water $(7 \%)$ are also used.

2. Improved PCMs, including microencapsulated PCM, SSPCM, acid, enhanced acid, and paraffin RT27, are used only in the cooling operation mode.

3. Acid and SSPCM have been applied mostly among modern backfill materials in GHEs, with usage frequencies of $30 \%$ and $28 \%$, respectively.

Generally, conventional backfill materials (pure and mixed material) are used more $(90 \%$ of instances) than modern backfill materials (10\%) in GHEs. The rate of use of modern backfill materials that have been studied numerically $(86 \%)$ is higher than those that have been studied experimentally $(14 \%)$. Moreover, for conventional backfill materials, the proportions of numerical and experimental studies are $55 \%$ and $45 \%$, respectively.

Despite conventional backfill materials having been used mostly in GHEs, in both primary operation modes, they are now often replaced with improved PCMs. This is in part because improving the heat exchange rate, GHE performance, and heat pump COP, as well as reducing thermal radius and accumulated electricity consumption of the heat pump, has become a significant focus of many researchers and engineers. Interestingly, these modern materials have been applied in the cooling operation mode only.

Since the data covered in this study are not from all the articles published in the last eight years, but rather from a subset based on specific criteria (i.e., English-language papers published in reputable journals), the results may have some corresponding limitations, but these are likely to be minor. In part, this is because the articles considered were published by authors from numerous countries. 
Author Contributions: All authors contributed substantially to all aspects of this article.

Funding: This research received no external funding.

Conflicts of Interest: The authors declare no conflict of interest.

\section{Nomenclature}

$\begin{array}{ll}Q & \text { Heat exchange rate, } \mathrm{W} \\ \varepsilon & \text { Effectiveness } \\ \mathrm{COP} & \text { Coefficient of performance }\end{array}$

\section{Abbreviations}

$\begin{array}{ll}\text { GSHP } & \text { Ground-source heat pump } \\ \text { GHE } & \text { Ground heat exchanger } \\ \text { PCM } & \text { Phase change material } \\ \text { PFA } & \text { Pulverized fuel ash } \\ \text { SSPCM } & \text { Shape-stabilized PCM } \\ \text { ENG } & \text { Expanded natural graphite } \\ \text { CENGg } & \text { Ground compressed ENG } \\ \text { CENGgx } & \text { CENGg with an apparent density } x\end{array}$

\section{References}

1. Solak, A.M.; Tenza-Abril, A.J.; Saval, J.M.; García-Vera, V.E. Effects of multiple supplementary cementitious materials on workability and segregation resistance of lightweight aggregate concrete. Sustainability 2018, 10, 4304. [CrossRef]

2. Letelier, V.; Ortega, J.; Tarela, E.; Muñoz, P.; Henríquez-Jara, B.; Moriconi, G. Mechanical performance of eco-friendly concretes with volcanic powder and recycled concrete aggregates. Sustainability 2018, 10, 3036. [CrossRef]

3. Dincer, I.; Rosen, M.A. Thermodynamic aspects of renewables and sustainable development. Renew. Sustain. Energy Rev. 2005, 9, 169-189. [CrossRef]

4. Alnahhal, M.F.; Alengaram, U.J.; Jumaat, M.Z.; Alqedra, M.A.; Mo, K.H.; Sumesh, M. Evaluation of industrial by-products as sustainable pozzolanic materials in recycled aggregate concrete. Sustainability 2017, 9, 767. [CrossRef]

5. Coppola, L.; Coffetti, D.; Crotti, E. Plain and ultrafine fly ashes mortars for environmentally friendly construction materials. Sustainability 2018, 10, 874. [CrossRef]

6. Al-Khoury, R. Computational Modeling of Shallow Geothermal Systems; CRC Press: Boca Raton, FL, USA, 2011.

7. Rosen, M.A.; Koohi-Fayegh, S. Geothermal Energy: Sustainable Heating and Cooling Using the Ground; John Wiley \& Sons: Hoboken, NJ, USA, 2017.

8. Delaleux, F.; Py, X.; Olives, R.; Dominguez, A. Enhancement of geothermal borehole heat exchangers performances by improvement of bentonite grouts conductivity. Appl. Thermal Eng. 2012, 33-34, 92-99. [CrossRef]

9. Lee, C.; Lee, K.; Choi, H.; Choi, H.-Y. Characteristics of thermally-enhanced bentonite grouts for geothermal heat exchanger in South Korea. Sci. China Ser. E Technol. Sci. 2010, 53, 123-128. [CrossRef]

10. Allan, M.L. Materials characterization of superplasticized cement-sand grout. Cement Concr. Res. 2000, 30, 937-942. [CrossRef]

11. Erol, S.; François, B. Efficiency of various grouting materials for borehole heat exchangers. Appl. Thermal Eng. 2014, 70, 788-799. [CrossRef]

12. Kavanaugh, S.P.; Allan, M.L. Testing of thermally enhanced cement ground heat exchanger grouts. ASHRAE Trans. 1999, 105, 446-450.

13. Zhang, W.; Yang, H.; Lu, L.; Fang, Z. Investigation on influential factors of engineering design of geothermal heat exchangers. Appl. Thermal Eng. 2015, 84, 310-319. [CrossRef] 
14. Borinaga-Treviño, R.; Pascual-Muñoz, P.; Castro-Fresno, D.; Blanco-Fernandez, E. Borehole thermal response and thermal resistance of four different grouting materials measured with a TRT. Appl. Thermal Eng. 2013, 53, 13-20. [CrossRef]

15. Chen, S.; Mao, J. Quantitative evaluation of improper backfilling in vertical borehole. J. Thermal Sci. Technol. 2016, 11, JTST00018. [CrossRef]

16. Kim, D.; Kim, G.; Kim, D.; Baek, H. Experimental and numerical investigation of thermal properties of cement-based grouts used for vertical ground heat exchanger. Renew. Energy 2017, 112, 260-267. [CrossRef]

17. Jun, L.; Xu, Z.; Jun, G.; Jie, Y. Evaluation of heat exchange rate of GHE in geothermal heat pump systems. Renew. Energy 2009, 34, 2898-2904. [CrossRef]

18. Allan, M.L.; Kavanaugh, S.P. Thermal conductivity of cementitious grouts and impact on heat exchanger length design for ground source heat pumps. HVACER Res. 1999, 5, 85-96.

19. Remund, C.P. Borehole thermal resistance: Laboratory and field studies. ASHRAE Trans. 1999, 105, 439-445.

20. Philippacopoulos, A.J.; Berndt, M.L. Influence of debonding in ground heat exchangers used with geothermal heat pumps. Geothermics 2001, 30, 527-545. [CrossRef]

21. Allan, M.; Philippacopoulos, A.J. Performance characteristics and modelling of cementitious grouts for geothermal heat pumps. In Proceedings of the World Geothermal Congress, Kyushu, Japan, 28 May-10 June 2000; Volume 28, pp. 3355-3360.

22. Smith, M.D.; Perry, R.L. Borehole grouting: Field studies and thermal performance testing. ASHRAE Trans. 1999, 105, 451-457.

23. Reuss, M.; Proell, M.; Koenigsdorff, R. Quality control of borehole heat exchanger systems. In Proceedings of the EFFSTOCK 09, 11th International Conference on Thermal Energy Storage, Stockholm, Sweden, 14-17 June 2009; pp. 104-112.

24. Herrmann, V.J. Engineering Geological Investigations on the Backfilling of Geothermal Boreholes with Geothermal Probes. PhD Dissertation, Karlsruhe Institute of Technology (KIT), Karlsruhe, Germany, 2008.

25. Di Bitetti, M.S.; Ferreras, J.A. Publish (in English) or perish: The effect on citation rate of using languages other than English in scientific publications. Ambio 2017, 46, 121-127. [CrossRef] [PubMed]

26. Guerrero-Bote, V.P. Félix Moya-Anegón. Downloads versus citations and the role of publication language. Res. Trends Issue 2014, 37, 19-22.

27. Van Leeuwen, T.N.; Moed, H.F.; Tijssen, R.J.W.; Visser, M.S.; van Raan, A.F.J. Language biases in the coverage of the Science Citation Index and its consequencesfor international comparisons of national research performance. Scientometrics 2001, 51, 335-346. [CrossRef]

28. Zhao, J.; Li, Y.; Wang, J. A review on heat transfer enhancement of borehole heat exchanger. Energy Procedia 2016, 104, 413-418. [CrossRef]

29. Noorollahi, Y.; Saeidi, R.; Mohammadi, M.; Hosseinzadeh, M.; Amiri, A. The effects of ground heat exchanger parameters changes on geothermal heat pump performance-a review. Appl. Thermal Eng. 2017, 129, 1645-1658. [CrossRef]

30. Pahud, D.; Matthey, B. Comparison of the thermal performance of double U-pipe borehole heat exchangers measured in situ. Energy Build. 2001, 33, 503-507. [CrossRef]

31. Choi, W.; Ooka, R. Effect of natural convection on thermal response test conducted in saturated porous formation: Comparison of gravel-backfilled and cement-grouted borehole heat exchangers. Renew. Energy 2016, 96, 891-903. [CrossRef]

32. Lee, C.; Park, S.; Lee, D.; Lee, I.; Choi, H. Viscosity and salinity effect on thermal performance of bentonite-based grouts for ground heat exchanger. Appl. Clay Sci. 2014, 101, 455-460. [CrossRef]

33. Kara, Y.A. Experimental performance evaluation of a closed-loop vertical ground source heat pump in the heating mode using energy analysis method. Int. J. Energy Res. 2007, 31, 1504-1516. [CrossRef]

34. Alberti, L.; Angelotti, A.; Antelmi, M.; la Licata, I. A numerical study on the impact of grouting material on borehole heat exchangers performance in aquifers. Energies 2017, 10, 703. [CrossRef]

35. Zhuang, Y.C.; Hong, S.Y.; He, X.K. Study on performance of backfilled soil for vertical-buried closed-loop GSHP. Acta Energiae Sol. Sin. 2004, 25, 216-220.

36. Carlson, S.W. GSHP bore field performance comparisons of standard and thermally enhanced grout. ASHRAE Trans. 2000, 106, 442-450.

37. Allan, M.L.; Philippacopoulos, A.L. Thermal Conductivity of Cementitious Grouts for Geothermal Heat Pumps; Brookhaven National Laboratory for US Department of Energy: Upton, NY, USA, November 1998. 
38. Eckhart, F. Grouting Procedures for Ground-source Heat Pump Systems; Ground Source Heat Pump Publications; Oklahoma State University: Stillwater, OK, USA, 1991.

39. Remund, C.P.; Lund, J.L. Thermal Enhancement of Bentonite Grouts for Vertical GSHP Systems. In Proceedings of the Heat Pump and Refrigeration Systems, Design, Analysis, and Applications, ASME Winter Annual Meeting, New Orleans, LA, USA, 28 November-3 December 1993; Volume 29, pp. 95-106.

40. Erol, S.; François, B. Freeze damage of grouting materials for borehole heat exchanger: Experimental and analytical evaluations. Geomechan. Energy Environ. 2016, 5, 29-41. [CrossRef]

41. $\mathrm{Xu}, \mathrm{Y}$;; Chung, D.D.L. Effect of sand addition on the specific heat and thermal conductivity of cement. Cement Concr. Res. 2000, 30, 59-61. [CrossRef]

42. Jobmann, M.; Buntebarth, G. Influence of graphite and quartz addition on the thermo-physical properties of bentonite for sealing heat-generating radioactive waste. Appl. Clay Sci. 2009, 44, 206-210. [CrossRef]

43. Desmedt, J.; van Bael, J.; Hoes, H.; Robeyn, N. Experimental performance of borehole heat exchangers and grouting materials for ground source heat pumps. Int. J. Energy Res. 2012, 36, 1238-1246. [CrossRef]

44. Allan, M.L.; Philippacopoulos, A.J. Properties and Performance of Cement-Based Grouts for Geothermal Heat Pump Applications; Brookhaven National Laboratory for US Department of Energy: Upton, NY, USA, November 1999.

45. Manso, J.M.; Gonzalez, J.J.; Polanco, J.A. Electric arc furnace slag in concrete. J. Mater. Civ. Eng. 2004, 16, 639-645. [CrossRef]

46. Manso, J.M.; Polanco, J.A.; Losanez, M.; Gonzalez, J.J. Durability of concrete made with EAF slag as aggregate. Cement Concr. Compos. 2006, 28, 528-534. [CrossRef]

47. Pellegrino, C.; Gaddo, V. Mechanical and durability characteristics of concrete containing EAF slag as aggregate. Cement Concr. Compos. 2009, 31, 663-671. [CrossRef]

48. Borinaga-Trevino, R.; Pascual-Munoz, P.; Castro-Fresno, D.; del Coz-Díaz, J.J. Study of different grouting materials used in vertical geothermal closed-loop heat exchangers. Appl. Thermal Eng. 2013, 50, 159-167. [CrossRef]

49. Yang, W.; Sun, L.; Wu, X. Energy storage and heat transfer characteristics of ground heat exchanger with phase change backfill materials. Trans. Chin. Soc. Agric. Eng. 2014, 30, 193-199.

50. Kassai, M.; Poleczky, L.; Al-Hyari, L.; Kajtar, L.; Nyers, J. Investigation of the energy recovery potentials in ventilation systems in different climates. Facta Univ. Ser. Mech. Eng. 2018, 16, 203-217. [CrossRef]

51. Rabin, Y.; Korin, E. Incorporation of phase-change materials into a ground thermal energy storage system: Theoretical study. J. Energy Resour. Technol. 1996, 118, 237-241. [CrossRef]

52. Bottarelli, M.; Georgiev, A.; Aydin, A.A.; Su, Y.; Yousif, C. Ground-source heat pumps using phase change materials. In Proceedings of the European Geothermal Congress, Pisa, Italy, 3-7 June 2013; pp. 84-89.

53. Kong, M.; Alvarado, J.L.; Thies, C.; Morefield, S.; Marsh, C.P. Field evaluation of microencapsulated phase change material slurry in ground source heat pump systems. Energy 2017, 122, 691-700. [CrossRef]

54. Wang, J.L.; de Zhao, J.; Liu, N. Numerical simulation of borehole heat transfer with phase change material as grout. Appl. Mech. Mater. 2014, 577, 44-47. [CrossRef]

55. Bottarelli, M.; Bortoloni, M.; Su, Y.; Yousif, C.; Aydın, A.A.; Georgiev, A. Numerical analysis of a novel ground heat exchanger coupled with phase change materials. Appl. Thermal Eng. 2015, 88, 369-375. [CrossRef]

56. Bottarelli, M.; Bortoloni, M.; Su, Y. Heat transfer analysis of underground thermal energy storage in shallow trenches filled with encapsulated phase change materials. Appl. Thermal Eng. 2015, 90, 1044-1051. [CrossRef]

57. Lei, H.; Zhu, N. Analysis of phase change materials (PCMs) used for borehole fill materials. Geotherm. Resour. Council Trans. 2009, 33, 93-98.

58. Benli, H.; Durmuş, A. Evaluation of ground-source heat pump combined latent heat storage system performance in greenhouse heating. Energy Build. 2009, 41, 220-228. [CrossRef]

59. Benli, H. Energetic performance analysis of a ground-source heat pump system with latent heat storage for a greenhouse heating. Energy Convers. Manag. 2011, 52, 581-589. [CrossRef]

60. Real, A.; García, V.; Domenech, L.; Renau, J.; Montés, N.; Sánchez, F. Improvement of a heat pump based HVAC system with PCM thermal storage for cold accumulation and heat dissipation. Energy Build. 2014, 83, 108-116. [CrossRef]

61. Moreno, P.; Castell, A.; Sole, C.; Zsembinszki, G.; Cabeza, L.F. PCM thermal energy storage tanks in heat pump system for space cooling. Energy Build. 2014, 82, 399-405. [CrossRef] 
62. Dehdezi, P.K.; Hall, M.R.; Dawson, A.R. Enhancement of soil thermo-physical properties using microencapsulated phase change materials for ground source heat pump applications. Appl. Mech. Mater. 2012, 110, 1191-1198. [CrossRef]

63. Bottarelli, M.; Bortoloni, M.; Georgiev, A.; Aydin, A.A.; Su, Y.; Yousif, C. Ground-source heat pumps: Benefits of using phase change materials. In Proceedings of the Sustainable Energy Storage in Buildings Conference, Dublin, Ireland, 19-21 June 2013; pp. 29-33.

64. Li, X.; Tong, C.; Duanmu, L.; Liu, L. Study of a U-tube heat exchanger using a shape-stabilized phase change backfill material. Sci. Technol. Built Environ. 2017, 23, 430-440. [CrossRef]

65. Tian, Y.; Zhao, C.Y. A numerical investigation of heat transfer in phase change materials (PCMs) embedded in porous metals. Energy 2011, 36, 5539-5546. [CrossRef]

66. Li, X.; Tong, C.; Duanmu, L.; Liu, L. Research on U-tube heat exchanger with shape-stabilized phase change backfill material. Procedia Eng. 2016, 146, 640-647. [CrossRef]

67. Chen, F.; Mao, J.; Chen, S.; Li, C.; Hou, P.; Liao, L. Efficiency analysis of utilizing phase change materials as grout for a vertical U-tube heat exchanger coupled ground source heat pump system. Appl. Thermal Eng. 2018, 130, 698-709. [CrossRef]

68. Assis, E.; Katsman, L.; Ziskind, G.; Letan, R. Numerical and experimental study of melting in a spherical shell. Int. J. Heat Mass Transfer 2007, 50, 1790-1804. [CrossRef]

69. Yan, L.H. Analytical and Experimental Study of Phase Change Materials Used as Backfill Material for Borehole Heat Exchangers. PhD Dissertation, Tianjin University, Tianjin, China, 2011.

70. Qi, D.; Pu, L.; Sun, F.; Li, Y. Numerical investigation on thermal performance of ground heat exchangers using phase change materials as grout for ground source heat pump system. Appl. Thermal Eng. 2016, 106, 1023-1032. [CrossRef]

71. Lei, H.; Dai, C. Comparative experiment of different backfill grouts for concentric ground heat exchangers. Geotherm. Resour. Council Trans. 2013, 37, 597-600.

(C) 2018 by the authors. Licensee MDPI, Basel, Switzerland. This article is an open access article distributed under the terms and conditions of the Creative Commons Attribution (CC BY) license (http:/ / creativecommons.org/licenses/by/4.0/). 